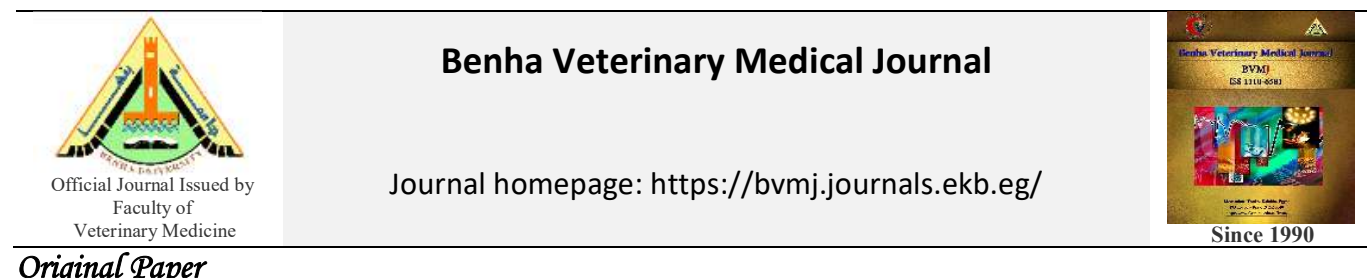

\title{
Effect of calving season and parity on the productivity and profitability of Holstein Friesian dairy farms
}

\author{
Amira M. Abd-El Hamed ${ }^{1, *}$, Sanad T. Atallah², Eman R. Kamel ${ }^{1}$ \\ ${ }^{1}$ Economics and Farm Management, Department of Animal Wealth Development, Faculty of Veterinary Medicine, Benha \\ University, Moshtohor, Toukh 13736, Qaliobia Egypt. \\ ${ }^{2}$ Economics, Marketing and Farm Management, Department of Animal Wealth Development, Faculty of Veterinary Medicine, \\ Alexandria University.
}

\begin{tabular}{|c|c|}
\hline ARTICLE INFO & ABSTRACT \\
\hline $\begin{array}{l}\text { Keywords } \\
305 M Y \\
\text { Calving season } \\
\text { Economic } \\
\text { Friesian Cows } \\
\text { Parity } \\
\text { Received } 25 / 08 / 2020 \\
\text { Accepted } 10 / 09 / 2020 \\
\text { Availa6le On-Line } \\
01 / 10 / 2020\end{array}$ & $\begin{array}{l}\text { The aim of this study is to evaluate the effect of calving season and parity on the productivity } \\
\text { and profitability of private and governmental dairy farms in Egypt. The data of this study were } \\
\text { estimated from } 1353 \text { lactation records of Friesian dairy cows. The data were classified } \\
\text { according to calving season into winter and summer calvers, and according to parity into six } \\
\text { lactation orders from } 1^{\text {st }} \text { to } 6^{\text {th }} \text {, then the data were analyzed statistically by using the computer } \\
\text { programs SPSS/PC+ version } 23 \text {. Total milk yield ( } 305 \mathrm{MY}) \text { and net profit (NP) differed } \\
\text { significantly between calving season and parity within production sector, private sector for } \\
\text { winter calvers and } 3^{\text {rd }} \text { parity had the highest } 305 \mathrm{MY} \text { and NP }(9759.5 \mathrm{Kg}-40960.9 \mathrm{EGP} \text { and } \\
10304.3 \mathrm{~kg} \text {, } 44546.1 \mathrm{EGP} \text {, respectively), while governmental sector for summer calvers and } \\
6^{\text {th }} \text { parity had the lowest } 305 \mathrm{MY} \text { and NP }(5028.4 \mathrm{Kg}-12117.1 \mathrm{EGP} \text { and } 4460.1 \mathrm{~kg} \text {, } 10027.3 \mathrm{EGP} \text {, } \\
\text { respectively). Total cost (TC) differed significantly within parity and sector, it was the highest } \\
\left.\text { for the private sector at } 4^{\text {th }} \text { parity ( } 34849.1 \mathrm{EGp}\right) \text {, while } 6^{\text {th }} \text { parity for governmental sector had } \\
\text { the lowest value }\left(27657.5 \mathrm{EGP).} \mathrm{Finally,} \mathrm{we} \mathrm{concluded} \mathrm{that} \mathrm{winter} \mathrm{calvers} \mathrm{and} 3^{\text {rd }} \text { parity }\right. \\
\text { achieve the highest profitability for dairy farms. }\end{array}$ \\
\hline
\end{tabular}

\section{INTRODUCTION}

Productive and reproductive efficiency of dairy cows affected by different non-genetic factors such as calving season, parity, and management. The productive efficiency indices are days in milk (DIM) and 305MY, while the reproductive indices are service per conception $(\mathrm{S} / \mathrm{C})$, days open (DO), and calving interval (CI) (Amene et al., 2011). In general, economic traits are controlled by genetic factors, but environmental factors like calving season, and parity have a significant effect on milk yield (Pirzada, 2011). These environmental factors might suppress the animal's true genetic ability and lead to a bias in the selection of animals, so these environmental effects have to be taken into account to estimate the genetic ability of animals in milk yield (Djemali and Berger, 1992). Several researchers revealed that an increase in the parity resulted in an increase in the milk yield up to the $4^{\text {th }}$ then declining (Hatungumukama et al., 2007; Badri et al., 2011). Also, Yilmaz and Koc (2013) and Al-Samarai et al. (2015) confirmed that the parity had a significant effect on $305 \mathrm{MY}$ of several breeds. Season of calving has an important impact on productive traits, as the high temperature severely depresses feed intake and milk yield (Amasaib et al., 2011). 305MY was observed to be higher during the rainy season due to higher levels of protein, energy, and minerals available to the lactating animals during this period (Gimbi, 2006). Several studies showed a significant effect of season of calving on milk yield of cows (Chegini et al., 2015; Faid-Allah, 2015; Petrović et al., 2015; Mikó et al., 2016). Atallah et al. (2015) showed that winter season and special sectors had the significant lead of milk production, also Mohamed et al. (2017) concluded that, the winter calving and first three parties were more profitable for Holstein dairy producers. However, other studies stated that there were no significant effects of calving season on milk yield (Badri et al., 2011; Usman et al., 2012; Mikó et al., 2016). In responding to the production sector, several studies showed that, the dairy production sector affects milk yield significantly (Rehman et al., 2008; Petrović et al., 2015). It might be due to variations in the level of management (Hadad, 2020). Improving the level of management is required for optimal reproduction performance (Mengistu and Wondimagegn, 2018). So, to improve the productivity and profitability of dairy cows, it is necessary to study variables affecting the animal's performance and farm economy. Therefore, our current study was planned to evaluate the effect of calving season and parity on the productivity and profitability of governmental and private dairy cow farms under subtropical Egyptian conditions.

\section{MATERIAL AND METHODS}

This study was carried out through field surveys in different regions of dairy cow farms (Cairo and Sharkia provinces) during the period extended from summer 2016 to winter

\footnotetext{
* Corresponding author: A. M Abd-El Hamed, Department of Animal Wealth Development, Faculty of Veterinary Medicine,

Benha University, Qaliobia, Egypt, E. mail: meroelfeky1000@gmail.com
} 
2019 on random samples of private and governmental production sectors.

The current work was approved by the Committee of Animal Care and Welfare, Benha University, Faculty of Veterinary Medicine, Egypt (BUFVTM:03-07-20).

\subsection{Animals and management}

Data used in this study were estimated from 1353 lactation records of Friesian dairy cows. All animals on the farm were housed in a free stall shaded open yards bedded with a sand floor, supplied with a cool spraying system during the summer season. Animals were grouped according to average daily milk yield (DMY) into fresh (from calving day till 60 days post-partum), high, medium, and low milk producing cows, all groups of cows were fed a balanced total mixed ration, although the diet composition differed according to the region, sector and management. Water was freely available at all times. Lactating cows were machine-milked two times per day with milk production was recorded at each milking. The collected data were milk production records and reproduction records.

\subsection{Productive traits:}

They included 305MY, DIM, DMY, and DPL. 305MY = $305 \times$ total milk yield/DIM (El-Tahaway, 2007 and Ahmed, 2011). DMY = Total milk yield per cow per lactation/ DIM. DPL (defined as the number of days between the dry-off date and the subsequent parturition date) (Capuco et al., 1997; Melendez and Pinedo, 2007).

\subsection{Reproductive traits:}

They included S/C (number of insemination doses till conception) calculated individually for each cow and DO.

\subsection{Economic indices:}

Calculations of costs and returns:

2.4.1. Fixed costs $=$ Depreciation cost of building + Depreciation cost of animal + Depreciation cost of parlor (Ahmed, 2011).

2.4.2. Variable costs $=$ Feed cost + Veterinary cost + Labor cost + Fuel cost (Ahmed, 2011).

2.4.3. Total costs $=$ Fixed costs + Variable costs $($ Kavoi et al., 2010).

2.4.4. Total returns $=$ Returns from milk sales (amount of $\mathrm{kg}$ milk produced $X$ price of $\mathrm{kg}$ milk) + Value of calves sold (price of one day old calf) + Fecal matter (amount of fecal matter produced $\mathrm{m}^{3} \mathrm{X}$ price of $\mathrm{m}^{3}$ ) (Ahmed, 2011).

2.4.5. Net profit $=$ Total returns - Total costs (Ribeiro et al., 2008).

\subsection{Data classification}

The data were classified according to (production sector, lactation order (parity), and calving season) into two production sectors private and governmental (El-Tahawy, 2007), six lactation orders from $1^{\text {st }}$ to $6^{\text {th }}$, two calving seasons (summer and winter) on basis of atmospheric temperature, humidity and rainfall into two seasons. Summer season extended from (21 March to 20 September) and winter season extended from (21 September to 20 March) (Attalla, 1997).

\subsection{Statistical analysis}

All statistical procedures were performed using the computer programs SPSS/PC ${ }^{+}$"version 23"(SPSS, 2015). Preliminary Levene's test was performed to ensure the homogeneity of variances among groups. The general linear model (GLM) procedure was used to analyze the productive, reproductive and economic measures for each animal according to fixed variables (Production sector, Calving season and Parity order) Duncan's Multiple Range-Test (Duncan, 1955) was used to test differences among means. Statistical significance between mean values was set at $(P \leq$ $0.05)$. Results were reported as means and standard error. This statistical model was constructed to determine the effect of interaction between fixed variables (Production sector, Calving season and Parity order) on some productive and reproductive variables and their costs and returns according to the following equation

$\mathrm{V}_{\mathrm{jkn}}=\mu+\mathrm{S}_{\mathrm{j}}+\mathrm{Se}_{\mathrm{k}}+\mathrm{P}_{\mathrm{n}}+(\mathrm{Se} \mathrm{x})_{\mathrm{kj}}+(\mathrm{Se} \mathrm{x})_{\mathrm{kn}}+\mathrm{e}_{\mathrm{jkn}}$ Where:

$\mathrm{V}_{\mathrm{jkn}}=$ the response variable.

$\mu=$ the overall mean of population.

$\mathrm{S}_{\mathrm{j}}=$ effect of $\mathrm{j}^{\text {th }}$ calving seasons (summer and winter).

$\mathrm{Se}_{\mathrm{k}}=$ effect of $\mathrm{k}^{\text {th }}$ sector (private and governmental).

$\mathrm{P}_{\mathrm{n}}=$ effect of $\mathrm{n}^{\text {th }}$ parity ( $1^{\text {st }}$ to $6^{\text {th }}$ parity order).

$(\text { Se } x \mathrm{~S})_{\mathrm{kj}}=$ effect of the interaction between $\mathrm{k}^{\text {th }}$ sector and $\mathrm{j}^{\text {th }}$ calving season.

$(\text { Se } x \text { P })_{k n}=$ effect of the interaction between $\mathrm{k}^{\text {th }}$ sector and $\mathrm{n}^{\text {th }}$ parity.

$\mathrm{e}_{\mathrm{jkn}}=\mathrm{un}$-explained error term.

\section{RESULTS}

3.1. Effect of calving season within production sector on some productive and reproductive traits of Holstein-Friesian dairy cows

Data summarizing results for the effect of calving seasons within the production sector on DIM, DMY, Milk yield, Dry period, $\mathrm{S} / \mathrm{C}$, and DO are presented in Tables (1 and 2).

DIM showed non-significant $(\mathrm{P}>0.05)$ increase for summer season calvers (374.3d) than winter calvers, it was (371.8 d), on the other side DIM increased significantly $(\mathrm{P}<0.05)$ within governmental sector than a private one, governmental sector for summer season calvers had the highest lactation length (387.0d), while private sector for summer calvers had the shortest lactation length (361.6d). DMY and 305MY were differed significantly $(\mathrm{P}<0.05)$ between calving seasons within the production sector, the private sector for winter calvers had the highest values $(32$ and $9759.5 \mathrm{~kg}$, respectively), while governmental sector for summer season calvers had the lowest values $(16.5$ and $5028.4 \mathrm{~kg}$, respectively). DP showed a significant increase in cows calved in summer season (75.2d) than in winter (70.8d), with non-significant effect within production sectors in the same season, either winter or summer. S/C and DO showed a nonsignificant increase for summer season calvers (4.1 and $222.5 \mathrm{~d}$, respectively) than in the winter season (4.0 and 217.3d, respectively).

3.2. Effect of calving season within sectors on collective efficiency measurements of Holstein-Friesian dairy cows. Data summarizing results for the effect of calving season within the production sector on economic indices are presented in Table (3). Calving season showed a nonsignificant increase on total production cost for winter season calvers (32100.8EGP) compared with the summer season (32004.5EGP). In responding to the production sector, TC showed a significant increase for the private sector than governmental one within both Calving season. Private sector cows that calved in winter season had the highest TC value (34609.7EGP), while governmental sector summer calving cows had the lowest value (29486.0 EGP). 
Calving season within the production sector had a significant effect on milk return, TR and NP, regarding winter season calvers they were $(52390.7,59242.3$ and 27141.4EGP, respectively), while summer season calvers were (50916.7, 57766.3 and 25761.8 EGP, respectively). Private sector cows that calved in winter season had the highest values (68316.2, 75570.6 and 40960.9 EGP, respectively), governmental sector summer calving cows had the lowest values (35198.6, 41642.4 and 12117.1 EGP, respectively).

\begin{tabular}{|c|c|c|c|c|c|c|}
\hline \multirow[t]{2}{*}{ Calving season } & Sector & NO. & DIM & DMY & $305 \mathrm{MY}$ & DPL \\
\hline & & & Mean \pm S.E & Mean \pm S.E & Mean \pm S.E & Mean \pm S.E \\
\hline \multirow{3}{*}{ Winter } & Private & 989 & $363.0^{\mathrm{b}} \pm 3.8$ & $32.0^{\mathrm{a}} \pm 0.3$ & $9759.5^{\mathrm{a}} \pm 83.0$ & $70.5^{\mathrm{b}} \pm 1.0$ \\
\hline & Gov. & 753 & $380.6^{\mathrm{a}} \pm 4.4$ & $17.1^{\mathrm{b}} \pm 0.3$ & $5209.3^{\mathrm{b}} \pm 95.1$ & $71.2^{\mathrm{b}} \pm 1.1$ \\
\hline & Total & 1742 & $371.8^{\mathrm{A}} \pm 2.9$ & $24.5^{\mathrm{A}} \pm 0.2$ & $7484.4^{\mathrm{A}} \pm 63.1$ & $70.8^{\mathrm{B}_{1}} \pm 0.7$ \\
\hline \multirow{3}{*}{ Summer } & Private & 751 & $361.6^{\mathrm{b}} \pm 4.4$ & $31.2^{\mathrm{a}} \pm 0.3$ & $9519.2^{\mathrm{a}} \pm 95.3$ & $75.5^{\mathrm{a}} \pm 1.1$ \\
\hline & Gov. & 602 & $387.0^{\mathrm{a}} \pm 4.9$ & $16.5^{b^{b}} \pm 0.3$ & $5028.4^{\mathrm{b}} \pm 106.4$ & $74.8^{\mathrm{a}} \pm 1.2$ \\
\hline & Total & 1353 & $374.3^{\mathrm{A}} \pm 3.3$ & $23.8^{\mathrm{B}} \pm 0.2$ & $7273.8^{\mathrm{B}} \pm 71.4$ & $75.2^{\mathrm{A}} \pm 0.8$ \\
\hline
\end{tabular}

Means within the same column carrying different superscripts (small letters) are significantly different $(\mathrm{P}<0.05)$. Means within the same column carrying different superscripts (capita letters) are significantly different $(\mathrm{P}<0.05)$. (Gov.): Governmental - (NO.): Number - (DIM): Days in milk - (DMY): Daily milk yield - 305MY: Total milk yield within 305 days- (DPL) Dry period length.

Table 2 Effect of calving season within sectors on some reproductive traits of Holstein-Friesian dairy cows.

\begin{tabular}{|c|c|c|c|c|}
\hline \multirow[t]{2}{*}{ Calving season } & Sector & NO. & Service/ conception (S/C) & Current days open (DO) \\
\hline & & & Mean \pm S.E & Mean \pm S.E \\
\hline \multirow{2}{*}{ Winter } & Private & 989 & $4.2^{\mathrm{ab}} \pm 0.1$ & $183.8^{b} \pm 4.5$ \\
\hline & Gov. & 753 & $4.0^{\mathrm{b}} \pm 0.1$ & $250.7^{\mathrm{a}} \pm 5.1$ \\
\hline \multirow{4}{*}{ Summer } & Total & 1742 & $4.0^{\mathrm{A}} \pm 0.1$ & $217.3^{\mathrm{A}} \pm 3.4$ \\
\hline & Private & 751 & $4.3^{\mathrm{a}} \pm 0.1$ & $188.9^{b} \pm 5.1$ \\
\hline & Gov. & 602 & $3.9^{\mathrm{b}} \pm 0.1$ & $256.1^{\mathrm{a}} \pm 5.7$ \\
\hline & Total & 1353 & $4.1^{\mathrm{A}} \pm 0.1$ & $222.5^{\mathrm{A}} \pm 3.8$ \\
\hline
\end{tabular}

Means within the same column carrying different superscripts (small letters) are significantly different $(\mathrm{P}<0.05)$. Means within the same column carrying different superscripts (capital letters) are significantly different $(\mathrm{P}<0.05)$ - (Gov.): Governmental - (NO.): Number.

\begin{tabular}{|c|c|c|c|c|c|c|}
\hline Calving season & Private & 989 & $34609.7^{a} \pm 74.0$ & $68316.2^{\mathrm{a}} \pm 581.1$ & $75570.6^{\mathrm{a}} \pm 581.1$ & $40960.9^{a} \pm 540.9$ \\
\hline \multirow{2}{*}{ Winter } & Total & 1742 & $32100.8^{\mathrm{A}} \pm 56.3$ & $52390.7^{\mathrm{A}} \pm 441.9$ & $59242.3^{\mathrm{A}} \pm 441.9$ & $27141.4^{\mathrm{A}} \pm 411.3$ \\
\hline & Private & 751 & $34483.6^{a} \pm 85.0$ & $66634.7^{\mathrm{a}} \pm 666.9$ & $73890.2^{\mathrm{a}} \pm 666.9$ & $39406.6^{a} \pm 620.7$ \\
\hline
\end{tabular}

Means within the same column carrying different superscripts (small letters) are significantly different $(\mathrm{P}<0.05)$. Means within the same column carrying different superscripts (capital letters) are significantly different $(\mathrm{P}<0.05)$. (Gover): Governmental - (NO.): Number - (TC): Total cost - (TR): Total return (NP): Net profit.

3.3. Effect of parity order and sector interaction on productive and reproductive performance of HolsteinFriesian dairy cows

Data summarizing results for the effect of parity within the production sector on DIM, DMY, 305MY, DPL, S/C, and DO are presented in Tables (4 and 5).

The average DIM differed significantly among different parities, not production sectors. Regarding parity orders they were $(385.1,362.2,375.3,371.2,333.5$ and $355.8 \mathrm{~d}$, respectively).The first parity for the governmental sector had the longest lactation length (395.0d), while the fifth parity for the governmental sector had the shortest lactation length (325.0d). The average DMY and 305MY were differed significantly among different parities within production sectors, regarding parity orders they were $(23.1,7053.7$ and 24.7, 7536.9 and 25.6, 7804.9 and 25.0, 7625.6 and 25.5, 7778.7 and $23.5,7165.1 \mathrm{~kg}$, respectively). The third parity for the Private sector had the highest value (33.8 and $10304.3 \mathrm{~kg}$, respectively), while the sixth parity for the governmental sector had the lowest value (14.6 and $4460.1 \mathrm{~kg}$, respectively). The average DPL differed significantly between the two sectors not parity, the highest value was recorded for the private sector at the second parity (77.6d), while the lowest value was for the governmental sector at the sixth parity (64.3d). The average $\mathrm{S} / \mathrm{C}$ neither differed significantly between the two sectors nor parities except for the sixth parity it differed significantly between private and governmental sectors (4.2 and 3.2), the highest value was for the fourth parity for the private sector (4.7), while the lowest value was for the sixth parity for the governmental sector (3.2). The average DO differ significantly between the two sectors not parities, the highest value was for the third parity of the governmental sector (257.8d), while the lowest value was for the second parity of the private sector $(176.9 \mathrm{~d})$

3.4. Effect of parity order within sectors on economic indices of Holstein-Friesian dairy cows.

Data summarizing results for the effect of parity production sector on economic indices are presented in Tables (6). TC was differed significantly among different parities within production sector, in responding to TC within parity order it was $(32045.5,31855.7,32301.7,32451.2,32582.0$ and 31099.2 EGP, respectively). 


\begin{tabular}{|c|c|c|c|c|c|c|}
\hline \multirow[t]{2}{*}{ Parity } & \multirow[t]{2}{*}{ Sector } & \multirow[t]{2}{*}{ NO. } & DIM & DMY & $305 \mathrm{MY}$ & DPL \\
\hline & & & Mean \pm S.E & Mean \pm S.E & Mean \pm S.E & Mean \pm S.E \\
\hline \multirow[t]{3}{*}{$1^{\text {st }}$} & Private & 696 & $375.2^{\mathrm{abc}} \pm 4.5$ & $29.5^{\mathrm{b}} \pm 0.3$ & $9005.8^{b} \pm 97.8$ & $68.9^{\mathrm{ab}} \pm 1.1$ \\
\hline & Gov. & 507 & $395.0^{\mathrm{a}} \pm 5.3$ & $16.7^{\mathrm{cd}} \pm 0.4$ & $5101.7^{\mathrm{cd}} \pm 114.6$ & $76.3^{\mathrm{a}} \pm 1.3$ \\
\hline & Total & 1203 & $385.1^{\mathrm{A}} \pm 3.5$ & $23.1^{\mathrm{C}} \pm 0.2$ & $7053.7^{C} \pm 75.4$ & $72.6^{\mathrm{A}} \pm 0.9$ \\
\hline \multirow[t]{3}{*}{$2^{\text {nd }}$} & Private & 468 & $347.8^{\mathrm{bcd}} \pm 5.5$ & $33.0^{\mathrm{a}} \pm 0.4$ & $10068.8^{\mathrm{a}} \pm 119.3$ & $77.6^{\mathrm{a}} \pm 1.4$ \\
\hline & Gov. & 443 & $376.5^{\mathrm{abc}} \pm 5.7$ & $16.4^{\mathrm{cd}} \pm 0.4$ & $5005.0^{\mathrm{cd}} \pm 122.6$ & $72.7^{\mathrm{ab}} \pm 1.4$ \\
\hline & Total & 911 & $362.2^{\mathrm{ABC}} \pm 4.0$ & $24.7^{\mathrm{BC}_{ \pm 0} 0.3}$ & $7536.9^{\mathrm{BC}} \pm 85.5$ & $75.1^{\mathrm{A}} \pm 1.0$ \\
\hline \multirow[t]{3}{*}{$3^{\text {rd }}$} & Private & 290 & $361.8^{\mathrm{abcd}} \pm 7.0$ & $33.8^{\mathrm{a}} \pm 0.5$ & $10304.3^{\mathrm{a}} \pm 151.6$ & $69.9^{\mathrm{ab}} \pm 1.8$ \\
\hline & Gov. & 213 & $388.7^{7^{\mathrm{ab}} \pm 8.2}$ & $17.4^{c} \pm 0.6$ & $5305.6^{\mathrm{c}} \pm 176.9$ & $68.1^{\mathrm{ab}} \pm 2.0$ \\
\hline & Total & 503 & $375.3^{\mathrm{AB}_{ \pm}}$ & $25.6^{\mathrm{A}} \pm 0.4$ & $7804.9^{A} \pm 116.5$ & $69.0^{A} \pm 1.3$ \\
\hline \multirow[t]{3}{*}{$4^{\text {th }}$} & Private & 167 & $363.9^{\mathrm{abcd}} \pm 9.3$ & $32.7^{\mathrm{a}} \pm 0.7$ & $9986.3^{\mathrm{a}} \pm 199.7$ & $76.5^{\mathrm{a}} \pm 2.3$ \\
\hline & Gov. & 120 & $378.5^{\mathrm{abc}} \pm 10.9$ & $17.3^{\mathrm{cd}} \pm 0.8$ & $5264.9^{\mathrm{cd}} \pm 235.6$ & $69.7^{\mathrm{ab}} \pm 2.7$ \\
\hline & Total & 287 & $371.2^{\mathrm{AB}^{\mathrm{A}} \pm 7.2}$ & $25.0^{\mathrm{AB}} \pm 0.5$ & $7625.6^{\mathrm{AB}} \pm 154.4$ & $73.1^{\mathrm{A}} \pm 1.8$ \\
\hline \multirow[t]{3}{*}{$5^{\text {th }}$} & Private & 87 & $342.1^{\mathrm{cd}} \pm 12.8$ & $32.0^{\mathrm{ab}} \pm 0.9$ & $9758.1^{\mathrm{ab}} \pm 276.7$ & $76.4^{\mathrm{a}} \pm 3.2$ \\
\hline & Gov. & 47 & $325.0^{\mathrm{d}} \pm 17.5$ & $19.0^{c} \pm 1.2$ & $5799.3^{c} \pm 376.5$ & $70.0^{\mathrm{ab}} \pm 4.4$ \\
\hline & Total & 134 & $333.5^{\mathrm{C}} \pm 10.8$ & $25.5^{\mathrm{A}} \pm 0.8$ & $7778.7^{\AA} \pm 233.6$ & $73.2^{\mathrm{A}} \pm 2.7$ \\
\hline \multirow[t]{3}{*}{$6^{\text {th }}$} & Private & 32 & $351.0^{\mathrm{bcd}} \pm 21.2$ & $32.4^{\mathrm{a}} \pm 1.5$ & $9870.1^{\mathrm{a}} \pm 456.3$ & $77.3^{\mathrm{a}} \pm 5.3$ \\
\hline & Gov. & 25 & $360.6^{\text {abcd }} \pm 24.0$ & $14.6^{\mathrm{d}} \pm 1.7$ & $4460.1^{\mathrm{d}} \pm 516.2$ & $64.3^{\mathrm{b}} \pm 6.0$ \\
\hline & Total & 57 & $355.8^{\mathrm{BC}} \pm 16.0$ & $23.5^{\mathrm{BC}} \pm 1.1$ & $7165.1^{\mathrm{BC}} \pm 344.5$ & $70.8^{\mathrm{A}} \pm 4.0$ \\
\hline
\end{tabular}

Means within the same column carrying different superscripts (small letters) are significantly different $(\mathrm{P}<0.05)$. Means within the same column carrying different superscripts (capital letters) are significantly different (P < 0.05). (Gov.): Governmental - (NO.): Number - (DIM): Days in milk - (DMY): Daily milk yield - (305MY): Total milk yield within 305 days- (DPL): Dry period length.

Table 5 Effect of parity order within sectors on some reproductive traits of Holstein-Friesian dairy cows.

\begin{tabular}{|c|c|c|c|c|}
\hline $\begin{array}{l}\text { Parit } \\
\mathrm{y}\end{array}$ & Sector & NO. & $\begin{array}{c}\text { Service/ Conception } \\
(\mathrm{S} / \mathrm{C})\end{array}$ & $\begin{array}{c}\text { Current days open } \\
\text { (DO) }\end{array}$ \\
\hline \multirow{3}{*}{$1^{\text {st }}$} & Privat & 696 & $4.3^{\mathrm{a}} \pm 0.1$ & $184.5^{\mathrm{bc}} \pm 5.3$ \\
\hline & $\begin{array}{l}\text { e } \\
\text { Gov. }\end{array}$ & 507 & $3.8^{\mathrm{ab}} \pm 0.1$ & $256.7^{\mathrm{a}} \pm 6.2$ \\
\hline & Total & $\begin{array}{l}120 \\
3\end{array}$ & $4.0^{\mathrm{A}} \pm 0.1$ & $220.6^{\mathrm{A}} \pm 4.1$ \\
\hline \multirow[t]{2}{*}{$2^{\text {nd }}$} & $\begin{array}{l}\text { Privat } \\
\text { e } \\
\text { Gov. }\end{array}$ & 468 & $4.0^{\mathrm{ab}} \pm 0.1$ & $176.9^{c} \pm 6.5$ \\
\hline & Total & 911 & $4.0^{\mathrm{A}} \pm 0.1$ & $215.6^{\mathrm{A}} \pm 4.6$ \\
\hline \multirow[t]{3}{*}{$3^{\text {rd }}$} & $\begin{array}{l}\text { Privat } \\
\mathrm{e}\end{array}$ & 290 & $4.3^{\mathrm{a}} \pm 0.2$ & $181.5^{\circ} \pm 8.2$ \\
\hline & Gov. & 213 & $4.3^{\mathrm{a}} \pm 0.2$ & $257.8^{\mathrm{a}} \pm 9.6$ \\
\hline & Total & 503 & $4.3^{\mathrm{A}} \pm 0.1$ & $219.6^{\mathrm{A}} \pm 6.3$ \\
\hline \multirow[t]{3}{*}{$4^{\text {th }}$} & $\begin{array}{l}\text { Privat } \\
\mathrm{e}\end{array}$ & 167 & $4.7^{\mathrm{a}} \pm 0.2$ & $202.8^{\mathrm{bc}} \pm 10.8$ \\
\hline & Gov. & 120 & $4.0^{\mathrm{ab}} \pm 0.3$ & $251.1^{\mathrm{a}} \pm 12.8$ \\
\hline & Total & 287 & $4.4^{\mathrm{A}} \pm 0.2$ & $227.0^{\mathrm{A}} \pm 8.4$ \\
\hline \multirow[t]{3}{*}{$5^{\text {th }}$} & $\begin{array}{l}\text { Privat } \\
\mathrm{e}\end{array}$ & 87 & $4.1^{\mathrm{a}} \pm 0.3$ & $213.9^{\mathrm{abc}} \pm 15.0$ \\
\hline & Gov. & 47 & $3.7^{\mathrm{ab}^{\mathrm{b}}} \pm 0.4$ & $204.3^{\mathrm{bc}} \pm 20.4$ \\
\hline & Total & 134 & $3.9^{A} \pm 0.3$ & $209.1^{\mathrm{A}} \pm 12.7$ \\
\hline \multirow[t]{3}{*}{$6^{\text {th }}$} & $\begin{array}{l}\text { Privat } \\
\mathrm{e}\end{array}$ & 32 & $4.2^{\mathrm{a}} \pm 0.5$ & $230.9^{\mathrm{ab}} \pm 24.7$ \\
\hline & Gov. & 25 & $3.2^{b} \pm 0.6$ & $219.0^{\mathrm{abc}} \pm 28.0$ \\
\hline & Total & 57 & $3.7^{\mathrm{A}} \pm 0.4$ & $225.0^{\mathrm{A}} \pm 18.7$ \\
\hline
\end{tabular}

Means within the same column carrying different superscripts (small letters) are significantly different $(\mathrm{P}<0.05)$. Means within the same column carrying different superscripts (capital letters) are significantly different $(\mathrm{P}<0.05)$.

The fourth parity for the private sector had the highest value (34849.1EGp), while the sixth parity for the governmental sector had the lowest value (27657.5 EGP). Milk return, TR and NP were differed significantly among different parities within production sector, regarding Milk return, TR and NP within parity order they were $(49376.3,56222.6$ and 24177.1 - 52758.3, 59608.1 and 27752.4 - 54634.6, 61489.0 and $29187.4-53379.5,60242.7$ and $27791.5-$ $54450.9,61307.4$ and 28725.1-50155.9, 57009.6 and 25910.5 EGP, respectively) the highest values for milk return, TR and NP were recorded for the third parity for the private sector $(72130.2,79386.8$ and 44546.1 EGP, respectively), while the sixth parity for the governmental sector had the lowest values $(31221,37684.8$ and 10027.3 EGP, respectively).

\section{DISCUSSION}

This study aimed to evaluate the effects of calving season and parity order on the productivity and profitability of private and governmental dairy farms in Egypt.

The non-significant effect of calving season on lactation length might be due to uniformity in the availability of fodders and feed all over the year. This result is similar to Kaleri et al. (2017), Sharif et al. (2018) and Mundan et al. (2020), who found a non-significant effect of calving season on lactation period (LP). Also, Mote et al. (2019) explained that season of calving exerted a non-significant influence on DIM in Holstein Friesian $\times$ Gir crossbred, but it is on contrary with Usman et al. (2012), Hossein-Zadeh (2013) and Mohammed and Atta (2019), who concluded that season of calving had a significant effect on DIM of Holstein Friesian cows. In responding to the significant effect of the sector on lactation length, this might be due to the reason of better feeding management in the private sector that led to the early conception of these cows in comparison with the governmental one, this result on the same line with Hadad (2020), who concluded that the differences in LP due to the herd type were significant, while the effects of calving season on LP were not significant. On the contrary, Coffie (2014) found a non-significant effect of herd type on lactation length. Regarding the effect of calving season within the production sector on DMY and 305MY, they differed significantly within the two calving seasons. private sector winter calvers had the highest values, while governmental sector summer calvers had the lowest values, might be due to high temperature in summer that increased the respiratory rate and severely depresses feed intake and milk yield (Amasaib et al., 2011). In responding to different levels of milk production between the two production sectors, this result might be due to variation in the level of management. These results in agreement with Lazarević et al. (2013), who found a significant effect for the calving season and herd type on the milk yield, also Atallah et al. 
(2015), who recorded that calving season and special sectors had the significant lead of milk production, also Mikó et al. (2016), Kunbhar et al. (2017), Mohamed et al. (2017) and Mohammed and Atta (2019) found a significant increase of milk yield in winter season than in summer one, while disagreed with Bala et al. (2017) and Kaleri et al. (2017), who recorded a non-significant effect of calving season on milk yield. Regarding the significant increase of DPL in the summer rather than winter season, might be attributed to low availability of green fodder and high environmental temperatures in summer season, so DP may increase to relief heat stress, for the improvement of dry period better management should be followed (Suhail et al., 2010). This result agreed with Zewdu et al. (2015) and Kaleri et al. (2017), who found that DP affected significantly by calving season, as summer season had the longest period. In responding to the slight increase of DO in winter season might be due to the adverse effect of heat stress on conception rate and subsequently increase the number of $\mathrm{S} / \mathrm{C}$, these results are in agreement with Tadesse et al. (2010), who found a non-significant effect of calving season on DO, while Zewdu et al. (2015) and Kunbhar et al. (2017) recorded a significant increase of DO for summer season than winter one, also Melendez and Pinedo (2007), who recorded significant effect of calving season on S/C and DO, also Hammoud et al. (2010) and Mengistu and Wondimagegn (2018) showed a significant effect of calving season on DO.

In responding to the production sector, it had a nonsignificant effect on $\mathrm{S} / \mathrm{C}$ and DO. This agreed with Hadad (2020), who concluded that the production sector had a nonsignificant effect on CI. In contrary Rehman et al. (2008) found that CI differed significantly among different herds. Concerning the effect of calving season on TC, the nonsignificant increase of total production cost for winter season compared with summer season nearly agreed with Mohamed et al. (2017) who stated that feed cost and TC were significantly increased at winter season than summer one, while disagreed with Atallah et al. (2015), who found significant increase of feed cost in summer season rather than winter one. TC showed significant increase for private sector than governmental one within both seasons, this might be due to better management and high feed cost for the private sector than the governmental one for maximizing milk production. In responding to the effect of calving season on milk return, TR and NP, there was a significant effect of calving season within production sector on milk return, TR and NP, this result might be due to higher milk yield in the winter season and private sector than summer and governmental one, these results were in accordance with Ahmed (2011), Atallah et al. (2015) and Mohamed et al. (2017), who concluded that winter season had significantly higher profitability measures including milk return, total return and net return. Effect of parity order within production sector on some productive traits of HolsteinFriesian dairy cows. The average DIM differed significantly among different parities not production sectors. This result in accordance with Al-Samarai et al. (2015), Choudhary et al. (2017) and Hadad (2020), who found a significant effect of parity on lactation length, while disagreeing with M'hamdi et al. (2012), Wondifraw et al. (2013) and Yilmaz and Koc (2013) who showed a non-significant effect of parity order on DIM, also this result disagreed with Uddin et al. (2011) and Ahmed (2011), who concluded that production sector had a significant effect on lactation length. Concerning the effect of parity order within the production sector on DMY and 305 milk yield.

The average DMY and 305MY differed significantly among different parties and sectors, the third parity for Private sector had the highest value, while the sixth parity for governmental sector had the lowest value. This result might be attributed to the increase in cow's weight over the years and development of the udder tissue, and Milk yield increased till the age of 6 years after that it begins to decrease (Çardak, 2016), this result in the same line with Chegini et al. (2015), Faid-Allah (2015) and Gamaniel et al. (2019), who said that increase in parity order resulted in a significant increase in the milk yield. Also, Lazarević et al. (2013) and Petrović et al. (2015) concluded that milk yield was different significantly among different herds. This result might be due to managemental variation. Likewise, Hadad (2020) concluded that total milk yield affected significantly among parities and sectors.

\begin{tabular}{|c|c|c|c|c|c|c|}
\hline \multirow[t]{2}{*}{ Parity } & Sector & NO. & TC & Milk return & TR & NP \\
\hline & & & Mean \pm S.E & Mean \pm S.E & Mean \pm S.E & Mean \pm S.E \\
\hline \multirow[t]{3}{*}{$1^{\text {st }}$} & Private & 696 & $34342.7^{\mathrm{a}} \pm 87.4$ & $63040.9^{\mathrm{b}} \pm 684.9$ & $70294.0^{b} \pm 684.8$ & $35951.2^{b} \pm 637.3$ \\
\hline & Gov. & 507 & $29748.2^{\mathrm{cd}} \pm 102.4$ & $35711.6^{\mathrm{cd}} \pm 802.4$ & $42151.2^{\mathrm{cd}} \pm 802.4$ & $12403^{\mathrm{cd}} \pm 746.7$ \\
\hline & Total & 1203 & $32045.5^{\mathrm{B}} \pm 67.3$ & $49376.3^{\mathrm{C}_{ \pm}} \pm 527.5$ & $56222.6^{C} \pm 527.5$ & $24177.1^{C_{ \pm}} \pm 490.9$ \\
\hline \multirow[t]{3}{*}{$2^{\text {nd }}$} & Private & 468 & $34599.8^{\mathrm{a}} \pm 106.6$ & $70481.9^{\mathrm{a}} \pm 835.2$ & $77737.0^{\mathrm{a}} \pm 835.2$ & $43137.2^{\mathrm{a}} \pm 777.2$ \\
\hline & Gov. & 443 & $29111.6^{\mathrm{d}} \pm 109.6$ & $35034.7^{\mathrm{cd}} \pm 858.4$ & $41479.2^{\mathrm{cd}} \pm 858.4$ & $12367.6^{\mathrm{cd}} \pm 798.9$ \\
\hline & Total & 911 & $31855.7^{\mathrm{C}} \pm 76.4$ & $52758.3^{\mathrm{BC}_{ \pm} 598.9}$ & $59608.1^{\mathrm{BC}_{ \pm} 598.8}$ & $27752.4^{\mathrm{BC}} \pm 557.3$ \\
\hline \multirow[t]{3}{*}{$3^{\text {rd }}$} & Private & 290 & $34840.7^{\mathrm{a}} \pm 135.4$ & $72130.2^{\mathrm{a}} \pm 1061$ & $79386.8^{\mathrm{a}} \pm 1060.9$ & $44546.1^{\mathrm{a}} \pm 987.3$ \\
\hline & Gov. & 213 & $29762.7^{\mathrm{cd}} \pm 158.0$ & $37138.9^{c} \pm 1238$ & $43591.3^{\text {cd }} \pm 1238.0$ & $13828.6^{\mathrm{cd}} \pm 1152.1$ \\
\hline & Total & 503 & $32301.7^{\mathrm{AB}_{ \pm}}+104.1$ & $54634.6^{\mathrm{A}} \pm 815.2$ & $61489.0^{\AA} \pm 815.2$ & $29187.4^{\mathrm{A}} \pm 758.6$ \\
\hline \multirow[t]{3}{*}{$4^{\text {th }}$} & Private & 167 & $34849.1^{\mathrm{a}} \pm 178.5$ & $69904.5^{\mathrm{a}} \pm 1398.2$ & $77165.5^{\mathrm{a}} \pm 1398.1$ & $42316.5^{\mathrm{a}} \pm 1301.1$ \\
\hline & Gov. & 120 & $30053.4^{\mathrm{bc}} \pm 210.6$ & $36854.5^{\mathrm{cd}} \pm 1649.4$ & $43319.8^{\mathrm{cd}} \pm 1649.3$ & $13266.4^{\mathrm{cd}} \pm 1534.9$ \\
\hline & Total & 287 & $32451.2^{\mathrm{AB}} \pm 138.0$ & $53379.5^{\mathrm{AB}} \pm 1081.1$ & $60242.7^{\mathrm{AB}} \pm 1081.1$ & $27791.5^{\mathrm{AB}} \pm 1006.1$ \\
\hline \multirow[t]{3}{*}{$5^{\text {th }}$} & Private & 87 & $34506.4^{\mathrm{a}} \pm 247.3$ & $68306.9^{\mathrm{ab}} \pm 1937.1$ & $75561.5^{\mathrm{ab}} \pm 1937.0$ & $41055.0^{\mathrm{a}} \pm 1802.6$ \\
\hline & Gov. & 47 & $30658^{\mathrm{b}} \pm 336.4$ & $40595^{\mathrm{c}} \pm 2635.5$ & $47053.3^{\mathrm{c}} \pm 2635.4$ & $16395.3^{c} \pm 2452.6$ \\
\hline & Total & 134 & $32582.2^{\mathrm{A}} \pm 208.7$ & $54450.9^{\mathrm{A}} \pm 1635.4$ & $61307.4^{\mathrm{A}} \pm 1635.3$ & $28725.1^{\mathrm{A}} \pm 1521.9$ \\
\hline \multirow[t]{3}{*}{$6^{\text {th }}$} & Private & 32 & $34540.8^{\mathrm{a}} \pm 407.7$ & $69090.7^{\mathrm{a}} \pm 3194$ & $76334.5^{\mathrm{a}} \pm 3193.9$ & $41793.7^{\mathrm{a}} \pm 2972.3$ \\
\hline & Gov. & 25 & $27657.5^{\mathrm{e}} \pm 461.3$ & $31221^{\mathrm{d}} \pm 3613.7$ & $37684.8^{\mathrm{d}} \pm 3613.5$ & $10027.3^{\mathrm{d}} \pm 3362.8$ \\
\hline & Total & 57 & $31099.2^{\mathrm{C}_{ \pm}} \pm 307.8$ & $50155.9^{\mathrm{BC}_{ \pm}} 2411.5$ & $57009.6^{\mathrm{BC}_{ \pm}} 2411.3$ & $25910.5^{\mathrm{BC}_{ \pm}} 2244.0$ \\
\hline
\end{tabular}


On contrary, Choudhary et al. (2017) explained that parity order significantly affected total milk yield, as the mean values for the third lactation were higher than second lactation but lower than the first lactation. In responding to the effect of parity order and sector interaction on DP. The average DP differed significantly between the two sectors not parity. This result is close to Barozai et al. (2011), who showed that Holstein Friesian cattle that raised under intensive management had comparatively higher DP in $3^{\text {rd }}$ lactation cows, followed by cows in the $2^{\text {nd }}$ lactation, and $6^{\text {th }}$ parity had the lowest DPL, while disagreed with Usman et al. (2012), who explained that the effect of parity was nonsignificant on DP. Regarding the effect of parity order within production sector interaction on $\mathrm{S} / \mathrm{C}$. The average $\mathrm{S} / \mathrm{C}$ neither differed significantly between two sectors nor parities except for the sixth parity it differed significantly between private and governmental sectors. This result in accordance with Sattar et al. (2005), who explained that parity order had a non-significant effect on service period, while disagreed with Attalla (1997), who explained that the production sector had a significant effect on the number of $\mathrm{S} / \mathrm{C}$.

Concerning the effect of parity order within production sector on DO. The average DO varied significantly between the two sectors not parity. This result might be due to the variation in the management system, fertility traits and milk yield of cows within different sectors (Ahmed, 2011). This result is similar to Ansari-Lari et al. (2010), who recorded a non-significant effect of parity on DO, while Al-Timimy (2003) and Hadad (2020) found a non-significant effect of parity and sector on calving interval. While, Rehman et al. (2008) and Pirzada (2011) recorded a significant effect of parity on CI, also Mengistu and Wondimagegn (2018) showed that cows with first parity recorded the lowest DO, while the highest at the second parity. In responding to the effect of parity on economic indices, effect of parity within production sector on TC. TC differed significantly among different parities and sectors, the highest value was for the fifth parity, while the lowest value was for the sixth parity. This is on the contrary with Mohamed et al. (2017) who found that $1^{\text {st }}$ and $2^{\text {nd }}$ parities had higher total production cost than subsequent parities. Concerning the effect of parity within production sector on milk return, TR and NP. Milk return, TR and NP were differed significantly among different parities and sectors. This result is close to that of Vijayakumar et al. (2017), who found that a significant effect of lactation number $(\mathrm{P}<0.001)$ on $305 \mathrm{MY}$ where the maximum milk yield was during $3^{\text {rd }}$ lactation, Also Dangar and Vataliya (2015) showed that there is highly significant effect of parity on lactation milk yield, as the highest lactation milk yield was observed during $5^{\text {th }}$ parity and significant drop was clear after $8^{\text {th }}$ parity. These results disagreed with Mohamed et al. (2017), who concluded that $1^{\text {st }}$ and $3^{\text {rd }}$ parity had higher DMY and $305 \mathrm{MY}$ than subsequent lactations, so they showed a higher net return.

\section{CONCULSION}

This study revealed that calving season and parity play important roles in the productivity, profitability, and economic efficiency of Holstein Friesian dairy cows. The private sector for winter season calvers and the third parity had the highest $305 \mathrm{MY}$ and NP, while the governmental sector for summer season calvers and the sixth parity had the lowest values. TC differed significantly within parity and sector, not season, it was the highest value for the private sector at the fourth parity, while the sixth parity for the governmental sector had the lowest value. The private sector achieves higher farm profitability than the governmental one. Cows at the third to the fifth parity, and those calving in winter season had the best economic efficiency of Holstein Friesian dairy farms, so culling the dairy cow after $5^{\text {th }}$ parity is more profitable.

\section{CONFLICT OF INTEREST}

The author declares no conflict of interest.

\section{REFERENCES}

1. Ahmed, I.A.M., 2011. Economic analysis of productive and reproductive efficiency in dairy cattle, Ph.D. Vet. Medical Science, Menofia University - Sadat branch, Egypt

2. Al-Samarai, F., Abdulrahman, Y., Mohammed, F., Al-Zaidi, F., Al-Anbari, N., 2015. Comparison of several methods of sires evaluation for total milk yield in a herd of Holstein cows in Yemen. Open Veterinary Journal 5, 11-17.

3. Al-Timimy, A., 2003. Genetic Evaluation of Holstein Friesian Bulls at the Artificial Insemination Center in Abu-Ghraib. Unpublished M. Sc. Thesis. Agriculture College, University of Baghdad.

4. Amasaib, E., Fadel-Elseed, A., Mahala, A., Fadlelmoula, A., 2011. Seasonal and parity effects on some performance and reproductive characteristics of crossbred dairy cows raised under tropical conditions of the Sudan. Livestock Research for Rural Development 23, 1-6.

5. Amene, f., Tesfu, k., Kelay, b., 2011. Study on reproductive performance of Holstein-Friesian dairy cows at Alage dairy farm, Rift Valley of Ethiopia. Tropical Animal Health and Production 43, 581-586.

6. Ansari-Lari, M., Kafi, M., Sokhtanlo, M., Ahmadi, H.N., 2010. Reproductive performance of Holstein dairy cows in Iran. Tropical Animal Health and Production 42, 1277-1283.

7. Atallah, S.T., Al Shaikh, A.I., El-Ktany, E.M., 2015. Some Factors affecting Profitability of Dairy Farms. Alexandria Journal of Veterinary Sciences 45, 119-126.

8. Attalla, S.T., 1997. Economic and productive efficiency of veterinary management in dairy farms. Ph. D. Thesis, Fac. Vet. Medicine, Alex. Univ., Egypt.

9. Badri, T., Atta, M., Ibrahim, M.T., Gubartalla, K., 2011. Genetic and non-genetic factors affecting production potential of Butana dairy cows at Atbara Research Station, Sudan. Research Opinions in Animal and Veterinary Sciences. ISSN 2223-0343.

10. Bala, D., Momoh, O., Gwaza, S., 2017. Effects of Non-genetic Factors Affecting the Productive Performance of White Fulani and Friesian x White Fulani Genotypes in Kaduna, Nigeria. Journal of Applied Life Sciences International, 15, 1-7.

11. Barozai, Y.H., Rafeeq, M., Baloch, H., Shahzad, I., Hilal, B. Abbas, F., Jehan, M., 2011. Study on performance analysis of Holstein Fresien cattle under intensive management at government dairy farm, Pishin, Balochistan. Animal Biology and Animal Husbandry 3, 65-70.

12. Capuco, A., Akers, R., Smith, J., 1997. Mammary growth in Holstein cows during the dry period: Quantification of nucleic acids and histology. Journal of Dairy Science 80, 477-487.

13. Çardak, A.D., 2016. Effects of somatic cell count, parity and lactation stage on yield and components of milk in holsteinfriesian cows. Harran Üniv Vet Fak Derg 5, 34-39.

14. Chegini, A., Zadeh, N.G.H., Moghadam, H.H., 2015. Effect of calf sex on some productive, reproductive and health traits in Holstein cows. Spanish Journal of Agricultural Research 13, e0605, 7 pages.

15. Choudhary, B.L., Datt, M., Bhinchhar, B.K., 2017. Study of Lactation Length and Milk Yield of F1 (Tharparkar X Holstein Friesian) Crossbred Cow During Three Consecutive 
Lactation. International Journal of Current Microbiology and Applied Sciences 6, 1264-1270.

16. Coffie, I., 2014. Factors affecting milk yield, lactation length and milk compsition of dual-purpose cattle in Ashanti Region of Ghana. University of Education, Winneba.

17. Dangar, N., Vataliya, P., 2015. Factors Affecting Lactation Milk Yield in Gir Cattle.Indian Veterinary Journal 92, 71-73.

18. Djemali, M., Berger, P., 1992. Yield and reproduction characteristics of Friesian cattle under North African conditions. Journal of Dairy Science 75, 3568-3575.

19. El-Tahaway, A.S., 2007. cattle diseases and their effects on economic and productive efficiency of dairy farms. Ph.D. Faculty of Veterinary Medicine, Alex. Univ., Egypt.

20. El-Tahawy, A., 2007. Cattle diseases and their effects on economic and productive efficiency of dairy farms. PhD Vet. Med., Alex. Univ., Egypt.

21. Faid-Allah, E., 2015. Genetic and non-genetic analysis for milk production and reproductive traits in Holstein cattle in Egypt. Jurnal Ilmu Ternak dan Veteriner 20, 10-17.

22. Gamaniel, I., Egahi, J., Addass, P., 2019. Effect Year of Calving and Parity on the Productive Performance of Holstein Friesian Cows in Vom Nigeria. Asian Journal of Research in Animal and Veterinary Sciences 4, 1-8.

23. Gimbi, A., 2006. Assessment of reproductive performance of small holder dairy cattle in Rungwe district Tanzania and possible interventions. University of Agriculture, Thesis for Award of Ph.D. Degree at Sokoine Morogoro, Tanzania,. p. 270.

24. Hadad, J.M.A., 2020. Performance of Friesian, Simmental and Bokane Cows for Milk Traits in Erbil Province-Kurdistan. Salahaddin University-Erbil.

25. Hammoud, M., El-Zarkouny, S., Oudah, E., 2010. Effect of sire, age at first calving, season and year of calving and parity on reproductive performance of Friesian cows under semiarid conditions in Egypt. Archiva Zootechnica 13, 1-8.

26. Hatungumukama, G., Sidikou, D.I., Leroy, P., Detilleux, J., 2007. Effects of non-genetic and crossbreeding factors on daily milk yield of Ayrshire $\times($ Sahiwal $\times$ Ankole) cows in Mahwa station (Burundi). Livestock Science 110, 111-117.

27. Hossein-Zadeh, N.G., 2013. Factors affecting lactation length and effect of current lactation length on the subsequent production and reproduction in Iranian Holsteins. Tierzucht 56, 873-881.

28. Kaleri, R.R.K.H.A., Baloch, S.K., Kaleri, A., Mari, G.M., Mari, A., Shah, M.A., Chalgri, M.A., Kakar, I.U.H., Gopang, M.A., 2017. Performance evaluation of Holstein Frisian cattle under subtropical environment. Pure and Applied Biology (PAB) 6, 1314-1318.

29. Kavoi, M., Hoag, D.L., Pritchett, J., 2010. Measurement of economic efficiency for smallholder dairy cattle in the marginal zones of Kenya. Journal of Development and Agricultural Economics 2, 122-137

30. Kunbhar, H.K., Sharif, S.M., Rizwana, H., Rajput, Z.I., Leghari, R.A., Mughal, G., 2017. Effect of Season on Reproductive Performance of Bhagnari Cattle Managed Under Semi Intensive Management Condition. Vet Sci 3(5): $1-4$

31. Lazarević, M., Petrović, M.M., Pantelić, V., Ružić-Muslić, D., Bogdanović, V., Đedović, R., Petrović, M.D., 2013. Study of the variability of milk traits in the population of holstein friesian cattle in central serbia, Proceedings of the 10th International Symposium Modern Trends in Livestock Production, Belgrade, Serbia, October 2-4, 2013. Institute for Animal Husbandry, Belgrade-Zemun. Pp. 543-549.

32. M'hamdi, N., Bouallegue, M., Frouja, S., Ressaissi, Y., Brar, S.K., Hamouda, M.B., 2012. Effects of environmental factors on milk yield, lactation length and dry period in Tunisian Holstein cows, Milk Production-An Up-to-Date Overview of Animal Nutrition, Management and Health. IntechOpen DOI: $10.5772 / 50803$

33. Melendez, P., Pinedo, P., 2007. The association between reproductive performance and milk yield in Chilean Holstein cattle. Journal of dairy science $90,184-192$.

34. Mengistu, D.W., Wondimagegn, K.A., 2018. Evaluation of the reproductive performance of Holstein Friesian dairy cows in Alage ATVET college, Ethiopia. International Journal of Livestock Production 9, 131-139.

35. Mikó, J., Atasever, S., Kocsisné, G.M., Erdem, H., 2016. Nongenetic factors affecting milk yield, composition and somatic cell count in Hungarian Holstein cows. Kafkas Universitesi Veteriner Fakultesi Dergisi 22, 361-366.

36. Mohamed, N.I., Mahrous, U.E., Kamel, S.Z., 2017. Effects of breed, calving season and parity on productive and economic indices of dairy cows. Alex. J. Vet. Scie, 55(2): 68-76.

37. Mohammed, A., Atta, M., 2019. Effects of parity order, age at first calving and season of calving on productive performance of Friesian crossbred cattle in Sudan. Journal of Veterinary Medicine and Animal Production 8, 138-146.

38. Mote, M.G., Nimbalkar, C., Deokar, D., Gaikwad, U., 2019. Effect of genetic and non-genetic factors on first lactation production traits in crossbreds of gir with Holstein Frieson and Jersey cattle breeds. Agricultural Research, 9. 424-428.

39. Mundan, D., Zonturlu, A.K., Öztürk, Y., Akkuş, T., Kaçar, C. 2020. Effect of calving season, calving year and lactation number on the milk yield traits in Holstein Cows raising in Şanliurfa. Turkish Journal of Agriculture-Food Science and Technology 8, 313-317.

40. Petrović, D.M., Bogdanović, V., Petrović, M.M., Bogosavljević-Bošković, S., Đoković, R., Đedović, R. Rakonjac, S., 2015. Effect of non-genetic factors on standard lactation milk performance traits in simmental cows. Annals of Animal Science 15, 211-220.

41. Pirzada, R., 2011. Estimation of genetic parameters and variance components of milk traits in Holstein-Friesian and British-Holstein Dairy cows. Kafkas Univ. Vet. Fak. Derg 17, 463-467.

42. Rehman, Z.U., Khan, M.S., Bhatti, S.A., Iqbal, J., Iqbal, A., 2008. Factors affecting first lactation performance of Sahiwal cattle in Pakistan. Arch. Tierz. Dummerstorf 51, 305-317.

43. Ribeiro, A.C., McAllister, A.J., Queiroz, S.A.d., 2008. Profitability measures of dairy cows. Revista Brasileira de Zootecnia 37, 1607-1616.

44. Sattar, H.;, M.R., Niazi, A.A.K., Latif, M., 2005. Productive and reproductive performance of Holstein-Friesian cows in Pakistan. . Pakistan Vet J 25, 75-81.

45. Sharif, R.M., El-Nazair, B.A., Abdalla, S.A., Ishag, I.A., 2018 Productive Performance of Pure Friesian Cows Raised under Conditions of River Nile State, North Sudan. Research and Reviews: J. Dairy Sci. Tech. 7, 26-32.

46. SPSS, I., 2015. SPSS for Windows (Version 23) Chicago, Illinois: SPSS. Inc.

47. Suhail, S., Ahmad, I., Hafeez, A., Ahmed, S., Jan, D., Khan, S., Rehman, A., 2010. Genetic study of some reproductive of jersey cattle under subtropical conditions. Sarhad J. Agric 26, 87-91.

48. Tadesse, M., Thiengtham, J., Pinyopummin, A., Prasanpanich, S., 2010. Productive and reproductive performance of Holstein Friesian dairy cows in Ethiopia. Livestock Research for Rural Development, 22, Article \#34. Retrieved September 25, 2020, from http://www.lrrd.org/lrrd22/2/tade22034.htm

49. Uddin, M., Sultana, M., Ndambi, O., Alqaisi, O., Hemme, T. Peters, K., 2011. Milk production trends and dairy development in Bangladesh. Outlook on AGRICULTURE 40 , 263-271.

50. Usman, T., Guo, G., Suhail, S.M., Ahmed, S., Qiaoxiang, L., Qureshi, M.S., Wang, Y., 2012. Performance traits study of Holstein Friesian cattle under subtropical conditions. Journal of Animal and Plant Sciences 22, 92-95.

51. Vijayakumar, M., Park, J.H., Ki, K.S., Lim, D.H., Kim, S.B., Park, S.M., Jeong, H.Y., Park, B.Y., Kim, T.I., 2017. The effect of lactation number, stage, length, and milking frequency on milk yield in Korean Holstein dairy cows using automatic milking system. Asian-Australasian journal of animal sciences 30, 1093-1098.

52. Wondifraw, Z., Thombre, B., Bainwad, D., 2013. Effect of non-genetic factors on milk production of Holstein Friesian Deoni crossbred cows. International Journal of Livestock Production 4, 106-112.

53. Yilmaz, H., Koc, A., 2013. A research on milk yield, persistency, milk constituents and somatic cell count of Red 
Holstein cows raised under Mediterranean climatic conditions. Bulgarian Journal of Agricultural Science 19, 1401-1407.

54. Zewdu, W., Thombre, B., Bainwad, D., 2015. Studies on some non-genetic factors affecting reproductive performance of
Holstein Friesian Deoni crossbred cows. African Journal of AgriculturalResearch 10, 1508-1516. 